\title{
DONOR SELECTION: IMMUNOGENETICS AND HISTOCOMPATIBILITY
}

\author{
Margareth Afonso Torres' , Gisele Fabianne Rampim², Juliana Fernandes Cardoso' , Carmem \\ Vergueiro ${ }^{3}$, Noemi Farah Pereira ${ }^{4}$, Alberto Cardoso Martins Lima ${ }^{4}$.
}

1 Hospital Israelita Albert Einstein, Sao Paulo, SP - 2 Immunogenetics Institute, Associação Fundo de Incentivo à Pesquisa, AFIP, São Paulo - 3 Associação da Medula Óssea do Estado de São Paulo, São Paulo - 4 Immunogenetics Laboratory, Hospital de Clínicas, Federal University of Paraná, Curitiba, Brazil

\section{INTRODUCTION}

The selection of donors with adequate HLA compatibility is essential for the success of hematopoietic stem cell transplantation (HSCT) [1, 2]. HLA genotypically identical donors are the first choice, but only about $30 \%$ of patients have this possibility. Unrelated donors, umbilical cord blood, or haploidentical donors are alternatives for the remaining 70\%. (Level of evidence 2a; Grade of recommendation B).

\section{RECOMMENDATIONS FOR PATIENT HLA TYPING}

It is recommended high-resolution $\mathrm{HLA}-\mathrm{A},-\mathrm{B},-\mathrm{C}$, -DRB1, -DQB1, and -DPB1 typing for patients in search of related and unrelated donors.

\section{CONFIRMATION OF HLA TYPING (CT)}

- All patients referred to HSCT and their respective donors (related, unrelated, and umbilical cord blood) must have HLA typing confirmed with a second (new) sample before transplant.

- The purpose of the CT is to exclude possible errors related to the identification of samples after collection or laboratory errors in any of the pre-analytical, analytical, or post-analytical steps.

- It is mandatory that this verification be done before the patient starts pre-HSCT conditioning. CT can be done in medium resolution if the previous HLA typing was performed in high resolution.

- The transplanted patient may eventually need a second transplant. Therefore, complete HLA genotyping of the patient is required to search for a new donor as well as a cryopreserved DNA sample for further examination.

\section{SAMPLE COLLECTION RECOMMENDATIONS FOR HLA TYPING}

- Peripheral blood collected in EDTA (5 to $10 \mathrm{~mL}$ ).

- Saliva is an alternative in leukopenic patients post-chemotherapy,

- Patients with leukemia: if there are many immature cells in peripheral blood, the initial or confirmatory HLA typing should be performed on DNA isolated from oral mucosa cells or other tissue in order to avoid false homozygous results.

- Patients with Fanconi anemia: if the initial HLA typing is done with blood in EDTA, the confirmatory typing should be done on DNA isolated from oral mucosa cells, as these patients are prone to chromosomal breakages.

- Patients with Severe Combined Immunodeficiency Syndrome (SCID): collection of oral mucosa cells with the aid of swabs should preferably be utilized to avoid interference of possible maternal cells in the peripheral blood of these patients.

- Patient post-allogeneic HSCT: collection of oral mucosa cells with the aid of swabs.

Recommendations for related donor selection

- Request medium resolution HLA-A, -B, and -DRB1 typing of siblings, parents and/or children.

- Confirmatory Typing (CT): it is mandatory that HLA confirmatory typing of the selected donor be done in a second/new sample before the transplant is performed.

- CT resolution level: request the medium resolution typing of the pre-selected donor if the four paren- 
tal haplotypes were identified. Otherwise, request high-resolution typing including HLA-C, -DQB1, and -DPB1 loci.

- In the absence of a fully HLA matched sibling, request high resolution HLA typing if an HLA 11/12 related donor is selected. This kind of donor can be found among siblings

as a consequence of crossing-over process that results in recombinant haplotypes, i.e., new allelic combinations that differ from those in the parental haplotypes.

- Regarding haploidentical related donors, it is essential to choose a donor with one shared haplotype with the patient (minimum compatibility of 6/12 for HLA-A, -B, -C, -DRB1, -DQB1, and -DPB1). It is possible to occur additional compatibility in one or more loci of the non-shared HLA haplotype, although there is currently no evidence of a beneficial effect of this extra compatibility on HSCT $[3,4]$. Therefore, the selection criteria for haploidentical donors should be based on the presence or absence of antibodies against incompatible HLA antigens expressed by the donor (DSA) and other non-HLA factors $[5,6]$. (Level of evidence $2 b$; Grade of recommendation $B$ )

\section{RECOMMENDATIONS FOR UNRELATED DONOR SELECTION}

- Choose preferably HLA 8/8 donors considering HLA-A, -B, -C and -DRB1[7-9] loci to proceed to REDOME phase 3 , which consists of confirmatory typing (CT) of HLA-A, - B, -C, -DRB1, -DQB1, and -DPB1 genes. It is mandatory that $C T$ be performed with a new sample. (Level of evidence $2 b$; Grade of recommendation $\mathrm{B}$ )

- Prioritize donors with permissive HLA-DPB1 mismatches, according to the T-Cell Epitope (TCE) algorithm, when several HLA 8/8 matched donors are available. HLA-DPB1 alleles may also be assessed by the Expression model, which is based on the single nucleotide polymorphism (SNP) rs9277534 in the 3' untranslated region. In this model, the HLA-DPB1 alleles associated with rs9277534 $\mathrm{G}$ and $\mathrm{A}$ variants are classified as high and low-expression, respectively. The concomitant use of the TCE and Expression models may optimize the selection of permissive HLA-DPB1 mismatches. [9-11]. (Level of evidence 2b; Grade of recommendation $B$ )

- Prioritize HLA-DQB1 and -DRB3, -DRB4, -DRB5 matched donors $(12,13)$ when several HLA $8 / 8$ compatible donors are available. (Level of evidence $2 \mathrm{~b}$; Grade of recommendation B)
- When 8/8 (HLA-A, - B, -C, -DRB1) allele compatible donors are not available, then HLA 7/8 donors with the permissible HLA-C*03:03 vs. $C^{*}$ 03:04 incompatibility should be prioritized [14]. (Level of evidence $2 \mathrm{~b}$; Grade of recommendation B)

- In the HSCT for malignant diseases setting, when HLA 8/8 (HLA-A, -B, -C, -DRB1) allele compatible donors are not available, choose preferably HLA 7/8 donors whose incompatibility vector is the Host versus Graft (HvG) instead of bidirectional or Graft versus Host $(\mathrm{GvH})[15,16]$. When it comes to non-malignant diseases, there is evidence that unidirectional incompatibilities in the HvG vector can increase the risk of rejection, and as precaution, they should be avoided [17]. (Level of evidence 2b; Grade of recommendation $\mathrm{B}$ )

- The presence of HLA mismatches also adversely affect the outcomes of unrelated donor HSCT for non-malignant diseases. In a previous CIBMTR study, HLA mismatches were associated with increased risks of graft failure [17]. (Level of evidence $2 \mathrm{~b}$; Grade of recommendation B)

- In the selection of umbilical cord blood, it is recommended that a segment of the cord blood bag be utilized for HLA-A, -B, -C, -DRB1, -DQB1 and -DPB1 high resolution typing. It is suggested that the allelic compatibility be at least $5 / 8$, considering HLA-A, $-B,-C$ and -DRB1 loci $[18,19]$. (Level of evidence $2 b$; Grade of recommendation B)

\section{ANTI-HLA ANTIBODIES: IDENTIFICATION AND DSA ASSESSMENT}

- In selecting alternative donors, the search for anti-HLA antibodies and the analysis to identify donor-specific antibodies (DSA) is recommended to minimize the risk of graft failure [20-25], except when a donor is HLA genotypically identical including HLA-DPB1 locus (HLA 12/12). (Level of evidence $2 \mathrm{~b}$; Grade of recommendation $B$ )

- The test is performed by solid-phase assays on the Luminex platform, using panels of HLA isolated antigens (Single Antigen Beads - SAB). It is recommended the utilization of complementary technical resources for accurate designation of DSA whenever SAB results leave doubts about the veracity of positive or negative reactions. These resources may include CDC cross-match, flow cytometric cross-match, HLA phenotype panel, and others. The integration of the results revealed by SAB and by complementary tests, in addition to the information on patient's sensitizing events, is essential for greater precision in the estimation of post-transplant immunological risk. 
- In general, the probability of graft failure increases as the strength (MFI) of the DSA do so. In addition, some studies have shown that DSAs with MFI > 5000 are associated with an increased risk of rejection [25, 26]; therefore, they should be avoided. In the absence of a donor without DSA, it is recommended to carry out a desensitization protocol and respective monitoring. (Level of evidence 2b; Grade of recommendation C)

\section{TECHNICAL RECOMMENDATIONS FOR THE IDENTIFICATION OF ANTI-HLA ANTIBODIES}

- Sample Collection: the test for anti-HLA antibody identification is performed with the recipient's serum. The peripheral blood sample from the recipient should be collected in a dry tube or a gel serum separator tube followed by centrifugation to separate the serum.

- Transport: whenever possible separate the serum before shipment and transport preferably at a temperature between $2^{\circ}$ and $8^{\circ} \mathrm{C}$ (artificial ice). If this is not possible, ship the whole blood sample at room temperature (avoid extreme temperatures) to the laboratory where the serum will be separated. The serum sample should preferably be kept in a $-70^{\circ} \mathrm{C}$ freezer until the time of testing.

- Identification of anti-HLA antibodies: each clinical laboratory should choose the solid phase assays for detection (screening) and characterization ( $S A B$ $=$ isolated HLA molecules) of anti-HLA antibodies. All of the selected tests must be validated before their utilization in the clinical routine.

- Complementation of HLA typing for DSA analysis: receptor and donor HLA-A, -B, -C, -DRB1, -DQB1 and -DPB1 matched, may or may not be identical at HLA-DRB3, -DRB4, -DRB5, -DQA1 and -DPA1. Thus, when patient has antibodies specific to allelic products of these genes, it is necessary to type them in the donor. It is also suggested to type the recipient for HLA-DRB3, -DRB4, -DRB5, -DQA1, and -DPA1 loci because the knowledge of self HLA can contribute to the interpretation of $S A B$ test results.

- Frequency of testing: the identification of anti-HLA antibodies should be done when the patient starts the donor search process and reassessed with his recent serum after his donor has been selected, even in the absence of DSA in the initial test. This is due to the fact that the patient's immunological profile is dynamic and can be altered by several factors, being the transfusion of blood components one of the main factors. In addition, inflammatory processes resulting from infections or tissue damage can induce reactiva- tion of memory $B$ cells resulting in the production of DSAs regardless of re-exposure to alloantigen.

- Desensitization and post-transplant monitoring: when the patient is submitted to a desensitization protocol to remove DSA against the alternative donor (haploidentical, unrelated, umbilical cord blood or related with HLA incompatibility), it is recommended that the effectiveness of the procedure be monitored by determining the DSA strength after each of the steps [27-29]. In some cases, it is necessary to monitor DSA post-HSCT because a rebound effect may occur after the infusion of the allograft, and therapeutic intervention can be done in a timely manner to avoid graft failure [27]. The frequency of sample collection for post-desensitization and post-transplant monitoring should be customized for each patient according to the understanding between the transplant physician and the HLA Laboratory. (Level of evicence 2b; Grade of recommendation C)

\section{CHIMERISM TESTING FOR POST- HEMATOPOIETIC STEM CELL TRANSPLANTATION MONITORING}

- The evolution of HSCT is assessed by hematological recovery and chimerism analysis, as these parameters provide information on the hematopoietic reconstitution of the patients, which can be autologous, allogeneic, or chimeric. Chimerism testing must be performed because it is essential to assess engraftment, to diagnose graft rejection, graft dysfunction, and disease relapse [30-35]. (Level of evidence $2 \mathrm{~b}$; Grade of recommendation B)

- The post-HSCT chimerism monitoring has been assessed by the analysis of genetic markers distributed throughout the human genome that have variable numbers of tandem repeats (STRs).

- The identification of these markers must be done on the pre-transplant peripheral blood sample of the patient, and on a peripheral blood sample of the donor in order to define their respective genetic profiles based on the utilized STRs. Chimerism testing can be performed on total nucleated cells, but the test sensitivity can be increased by analyzing cell subpopulations in blood or bone marrow samples in the post-transplant.

\section{TECHNICAL RECOMMENDATIONS FOR CHIMERISM TESTING COLLECTION}

samples should preferably be collected in EDTA. The determination of the post-transplant chimerism level requires the identification of STR markers in the following samples: 
- Pre-transplant peripheral blood of the patient to define his/her pattern of allelic variants in the STR loci;

- Peripheral blood of the donor to define his/her pattern of allelic variants in the STR loci;

- Post-transplant peripheral blood or bone marrow of the patient to define if the alleles identified in the STR loci are only those of the patient or both patient and donor or only donor's.

\section{REFERENCES}

1.Tie R, Zhang T, Yang B, Fu H, Han B, Yu J, et al. Clinical implications of HLA locus mismatching in unrelated donor hematopoietic cell transplantation: a meta-analysis. Oncotarget. v.8, n.16,p. 27645-27660, 2017.

2.Kekre N, Mak KS, Stopsack KH, Binder M, Ishii K, Branvall E, et al. Impact of HLA-Mismatch in Unrelated Donor Hematopoietic Stem Cell Transplantation: A Meta-Analysis. Am J Hematol. v. 91, n.6, p.551-555,2016.

3.Kasamon $Y L$, Luznik L, Leffell MS, Kowalski J, Tsai HL, Bolanos-Meade J, et al. Nonmyeloablative HLA-haploidentical bone marrow transplantation with high-dose posttransplantation cyclophosphamide: effect of HLA disparity on outcome. Biol Blood Marrow Transplant. v.16, n.4,p.482-489, 2010.

4.Raiola AM, Risitano A, Sacchi N, Giannoni L, Signori $A$, Aquino $S$, et al. Impact of HLA Disparity in Haploidentical Bone Marrow Transplantation Followed by High-Dose Cyclophosphamide. Biol Blood Marrow Transplant. v.24, n.1, p. 119-126, 2018.

5.Kongtim P, Ciurea SO. Who is the best donor for haploidentical stem cell transplantation? Semin Hematol. v.56, n.3, p. 194- 200, 2019.

6.Ciurea SO, Al Malki MM, Kongtim P, Fuchs EJ, Luznik L, Huang XJ, et al. The European Society for Blood and Marrow Transplantation (EBMT) consensus recommendations for donor selection in haploidentical hematopoietic cell transplanta-

\section{TRANSPORTATION:}

samples must be stored and transported at room temperature $\left(15^{\circ}-25^{\circ} \mathrm{C}\right)$, mainly when the analysis of cell subpopulations is necessary. Refrigeration can compromise cell viability, and consequently the determination of sub-populations' purity by flow cytometric immunophenotyping.

- Time elapsed between collection and delivery of patient and donor samples to the laboratory should not exceed 24 hours, when destined for chimerism testing in cell sub-populations.

- The purity must be assessed in all cell fractions. Insufficiency of cells to evaluate the purity must be informed in the chimerism testing report.

tion. Bone Marrow Transplant. v.55,n.1, p.12-24, 2020.

7.Lee SJ, Klein J, Haagenson M, Baxter-Lowe LA, Confer DL, Eapen M, et al. High-resolution donor-recipient HLA matching contributes to the success of unrelated donor marrow transplantation. Blood. v. 110, n.13, p. 4576-4583, 2007.

8.Woolfrey A, Klein JP, Haagenson M, Spellman S, Petersdorf $\mathrm{E}$, Oudshoorn $\mathrm{M}$, et al. HLA-C antigen mismatch is associated with worse outcome in unrelated donor peripheral blood stem cell transplantation. Biol Blood Marrow Transplant. v.17,n.6,p.885-892,2011.

9.Pidala J, Lee SJ, Ahn KW, Spellman S, Wang HL, Aljurf $M$, et al. Nonpermissive HLA-DPB1 mismatch increases mortality after myeloablative unrelated allogeneic hematopoietic cell transplantation. Blood. v.124,n.16,p. 2596-606, 2014.

10.Arrieta-Bolanos E, Crivello P, Shaw BE, Ahn KW, Wang $\mathrm{HL}$, Verneris MR, et al. In silico prediction of nonpermissive HLA-DPB1 mismatches in unrelated HCT by functional distance. Blood Adv. v.2, n.14, p.1773-1783, 2018.

11.Petersdorf EW, Bengtsson M, De Santis D, Dubois V, Fleischhauer K, Gooley $\mathrm{T}$, et al. Role of HLA-DP Expression in Graft-Versus-Host Disease After Unrelated Donor Transplantation. J Clin Oncol. v.38,n.24, p.2712-2718, 2020.

12.Furst D, Muller C, Vucinic V, Bunjes D, Herr W, Gramatzki M, et al. High-resolution HLA matching in hematopoietic stem cell transplantation: 
a retrospective collaborative analysis. Blood. v.122, n.18, p.3220-3229, 2013.

13. Ducreux S, Dubois V, Amokrane K, Yakoub-Agha I, Labalette M, Michallet M, et al. HLA-DRB3/4/5 mismatches are associated with increased risk of acute GVHD in 10/10 matched unrelated donor hematopoietic cell transplantation. Am J Hematol. 2018.

14. Fernandez-Vina MA, Wang T, Lee SJ, Haagenson M, Aljurf M, Askar M, et al. Identification of a permissible HLA mismatch in hematopoietic stem cell transplantation. Blood. v.123, n.8, p.12701278, 2014.

15. Hurley CK, Woolfrey A, Wang $T$, Haagenson $M$, Umejiego J, Aljurf $M$, et al. The impact of HLA unidirectional mismatches on the outcome of myeloablative hematopoietic stem cell transplantation with unrelated donors. Blood. v.121, n.23, p.4800-4806,2013.

16. Kanda J, Ichinohe T, Fuji S, Maeda Y, Ohashi K, Fukuda T, et al. Impact of HLA mismatch direction on the outcome of unrelated bone marrow transplantation: a retrospective analysis from the Japan Society for Hematopoietic Cell Transplantation. Biol Blood Marrow Transplant. v.21, n.2, p.305-311, 2015.

17. Horan J, Wang T, Haagenson M, Spellman SR, Dehn J, Eapen M, et al. Evaluation of HLA matching in unrelated hematopoietic stem cell transplantation for nonmalignant disorders. Blood. v.120, n.14,p.2918-2924, 2012.

18.Eapen M, Klein JP, Ruggeri A, Spellman S, Lee SJ, Anasetti C, et al. Impact of allele-level HLA matching on outcomes after myeloablative single unit umbilical cord blood transplantation for hematologic malignancy. Blood. v..123, n.1, p.133-140, 2014.

19. Eapen M, Wang T, Veys PA, Boelens JJ, St Martin A, Spellman S, et al. Allele-level HLA matching for umbilical cord blood transplantation for non-malignant diseases in children: a retrospective analysis. The Lancet Haematology. v. 4, n.7, p. $325,333,2017$.

20. Spellman S, Bray R, Rosen-Bronson S, Haagenson $\mathrm{M}$, Klein J, Flesch $\mathrm{S}$, et al. The detection of donor-directed, HLA-specific alloantibodies in recipients of unrelated hematopoietic cell transplantation is predictive of graft failure. Blood. v.115,n.13,p.2704-2708, 2010.
21. Ciurea SO, Thall PF, Wang X, Wang SA, Hu Y, Cano $P$, et al. Donor-specific anti-HLA Abs and graft failure in matched unrelated donor hematopoietic stem cell transplantation. Blood. v.118,n.22, p.5957-5964, 2011.

22. Takanashi M, Atsuta Y, Fujiwara K, Kodo H, Kai S, Sato $\mathrm{H}$, et al. The impact of anti-HLA antibodies on unrelated cord blood transplantations. Blood. v.116, n.15, p.2839-2846, 2010.

23. Fuji S, Oshima K, Ohashi K, Sawa M, Saito T, Eto $\mathrm{T}$, et al. Impact of pretransplant donor-specific anti-HLA antibodies on cord blood transplantation on behalf of the Transplant Complications Working Group of Japan Society for Hematopoietic Cell Transplantation. Bone Marrow Transplant. v.55, n.4, p.722-728, 2020.

24. Zou J, Romee R, Slade M, Phelan D, Keller J, Mohanakumar T, et al. Untreated donor specific antibodies against HLA are associated with poor outcomes in peripheral blood haploidentical hematopoietic cell transplantation. Bone Marrow Transplant. v.52, n.6, p. 898-901, 2017.

25. Ciurea SO, Thall PF, Milton DR, Barnes TH, Kongtim P, Carmazzi $Y$, et al. Complement-Binding Donor-Specific Anti-HLA Antibodies and Risk of Primary Graft Failure in Hematopoietic Stem Cell Transplantation. Biol Blood Marrow Transplant. v.21, n.8, p. 1392-1398, 2015.

26. Yoshihara S, Maruya E, Taniguchi K, Kaida K, Kato $R$, Inoue $T$, et al. Risk and prevention of graft failure in patients with preexisting donor-specific HLA antibodies undergoing unmanipulated haploidentical SCT. Bone Marrow Transplant. v.47,n.4, p. 508-515, 2012.

27.Leffell MS, Jones RJ, Gladstone DE. Donor HLA-specific Abs: to BMT or not to BMT? Bone Marrow Transplant. v.50. n.6, p.751-758, 2015.

28. Ciurea SO, Kongtim P, Zou J, Aung F, Gendzekhadze $K$, Taniguchi $M$, et al. Desensitization Therapy for Patients with DSA Receiving Haploidentical (Haplo) Stem Cell Transplantation. Biology of Blood and Marrow Transplantation. v.26,n.3,p.296-297, 2020.

29. Chang YJ, Xu LP, Wang Y, Zhang XH, Chen H, Chen $\mathrm{YH}$, et al. Rituximab for desensitization during HLA-mismatched stem cell transplantation in patients with a positive donor-specific anti-HLA antibody. Bone Marrow Transplant. v.55,n.7,p.1326-1336,2020. 
30. Reshef R, Hexner EO, Loren AW, Frey NV, Stadtmauer EA, Luger SM, et al. Early donor chimerism levels predict relapse and survival after allogeneic stem cell transplantation with reduced-intensity conditioning. Biol Blood Marrow Transplant. v.20, n.11, p.1758-1766, 2014.

31. Mellgren K, Arvidson J, Toporski J, Winiarski J. Chimerism analysis in clinical practice and its relevance for the detection of graft rejection and malignant relapse in pediatric hematopoietic stem cell transplant patients. Pediatr Transplant. v.19, n.7, p.758-766, 2015.

32. Mossallam Gl, Kamel AM, Storer B, Martin PJ. Prognostic utility of routine chimerism testing at 2 to 6 months after allogeneic hematopoietic cell transplantation. Biol Blood Marrow Transplant. v.15, n.3, p.352-359, 2009.
33. Tang $X$, Alatrash G, Ning J, Jakher $H$, Stafford $P$, Zope $M$, et al. Increasing chimerism after allogeneic stem cell transplantation is associated with longer survival time. Biol Blood Marrow Transplant. v.20,n.8,p.1139-1144, 2014.

34. Ahci $M$, Stempelmann $K$, Buttkereit U, Crivello $P$, Trilling $M$, Heinold $A$, et al. Clinical Utility of Quantitative PCR for Chimerism and Engraftment Monitoring after Allogeneic Stem Cell Transplantation for Hematologic Malignancies. Biol Blood Marrow Transplant. v.23,n.10,p.1658-1668, 2017.

35. Gabr H, Youssry I, El-Ansary Y, Mosallam G, Riad NM, Hanna MOF. Chimerism in pediatric hematopoietic stem cell transplantation and its correlation with the clinical outcome. Transp/ Immunol. v.45,p. 53-58, 2017. 